\title{
STRATEGI POSITIONING DAN DIFERENSIASI DALAM UPAYA MEMBANGUN BRAND, STUDI KASUS NGAYOGJAZZ
}

\author{
Agnes Tika Setiarini \\ agnes.tieka@gmail.com
}

\begin{abstract}
Abstrak
Ngayogjazz adalah salah satu festival musik jazz yang diselenggarakan rutin setiap satu tahun sekali di Yogyakarta. Festival ini mengalami peningkatan jumlah penonton yang signifikan setiap tahunnya. Keberhasilan Ngayogjazz ini adalah salah satu hasil dari strategi pemasaran yang dijalankan. Strategi pemasaran yang baik akan menjadi penentu suksesnya pemasaran sebuah produk. Segitiga positioning, diferensiasi, brand (PDB) adalah salah satu pengembangan dari konsep pemasaran oleh Kertajaya. Teori ini dapat menjadi landasan untuk menentukan strategi positioning dan diferensiasi yang tepat bagi sebuah produk. Penelitian ini difokuskan pada penerapan teori segitiga PDB dalam Ngayogjazz. Metode penelitian menggunakan metode kualitatif pendekatan studi kasus. Pengumpulan data dilakukan melalui indepth interview. Hasil dari penelitian ini adalah rumusan upaya-upaya strategi positioning dan diferensiasi dalam festival Ngayogjazz. Kesimpulan yang dihasilkan, penerapan segitiga PDB dalam Ngayogjazz penting dilakukan agar penyelenggara mengetahui sejauh mana maksudnya tersampaikan pada masyarakat. Hasil dari analisis menggunakan segitiga PDB, Ngayogjazz telah membentuk sebuah brand sebagai festival musik jazz yang memiliki karakter kota Yogyakarta.
\end{abstract}

Kata kunci: festival musik, strategi pemasaran, segitiga PDB.

\begin{abstract}
Ngayogjazz is one of the jazz festivals held regularly in Yogyakarta. The number of audiences in this festival has increased significantly every year. The success of Ngayogjazz is one of the results of its marketing strategy. A good marketing strategy will determine the success of the product and will also build a strong brand for itself. Positioning, differentiation, and brand (PDB) is one of the developments of Kertajaya's marketing concept. PDB Triangle could be the basis for determining the appropriate positioning and differentiation strategies for a product.

The research focuses on the application of PDB triangular theory in Ngayogjazz, using qualitative method with case study approach. Data is collected through in-depth interview. These methods can measure to which extent does Ngayogjazz applies marketing theory (in this case, positioning and differentiation). The results from this study is the formulation of positioning and differentiation strategy in Ngayogjazz festival. This study concludes that the application of the PDB triangle in Ngayogjazz is important so that the organizers know to which extent the intention is conveyed to the public. The results of the analysis using PDB triangle shows that Ngayogjazz has formed a brand as a jazz music festival that wears the characteristics of the city of Yogyakarta.
\end{abstract}

Keywords: music festivals, marketing strategy, triangular PDB 


\section{Pendahuluan}

Yogyakarta diisukan sebagai kota festival sejak sekitar dua tahun yang lalu. Isu ini ditulis dalam Kompasiana.com pada sebuah artikel dengan judul Jogja Kota Festival (2014). British Council (www.britishcouncil.id), sebuah lembaga organisasi budaya Inggris yang bergerak di bidang pendidikan adalah salah satu lembaga yang menggemakan hal ini. Sejak 2014, British Council bekerjasama dengan festival-festival besar di Yogyakarta mengembangkan konsep promosi dan pemasaran agar dapat dibawa ke level internasional, harapannya dapat membentuk citra "kota festival" di Yogyakarta. Program inisiatif British Council ini memandang hubungan budaya dengan edukasi, pariwisata, dan ekonomi kreatif di Yogyakarta.

Festival-festival seni pertunjukan yang berlangsung di Yogyakarta terbentuk berdasarkan intuisi dan kekuatan visi para penyelenggara sebagai salah satu wujud peristiwa kebudayaan. Beberapa festival besar terselenggara di Yogyakarta misalnya FKY, ArtJog, Biennale Jogja, JAFF, Festival Film Dokumenter, Ngayogjazz, Malioboro Night Festival, Festival Gamelan Internasional, dan banyak lagi. Ajang-ajang ini diselenggarakan dalam berbagai bentuk dan dengan berbagai tujuan. Seniman, budayawan, dan para penyelenggara festival di Yogyakarta telah menyadari kontribusi besar festival bagi pembangunan banyak aspek dalam kehidupan masyarakat.

Melihat besarnya dampak dan peran festival bagi banyak aspek dalam kehidupan masyarakat, festival seperti mengalami perluasan makna dari sebuah peristiwa kebudayaan sampai sebuah 'produk' kebudayaan (kesenian). Perubahan bentuk dan fungsi festival juga menuntut perubahan pengelolaan festival. Pengelolaan yang baik dimaksudkan agar festival tetap memiliki esensi yang kuat sebagai peristiwa kebudayaan sekaligus memberi kontribusi positif bagi banyak sektor lain dalam kehidupan manusia. Penyelenggara festival harus memiliki konsep yang kuat dan sesuai agar tercipta posisi yang tepat dalam benak masyarakat. Posisi yang tepat dapat menjadi identitas yang kuat, yang dapat menjadi aset keberlangsungan kegiatan itu sendiri. Penciptaan posisi yang kuat dalam benak masyarakat dapat didukung salah satunya dengan menciptakan konsep diferensiasi (pembeda).

Ngayogjazz adalah salah satu festival musik jazz yang memiliki posisi yang kuat dalam benak masyarakat Yogyakarta. Posisi ini juga tidak lepas dari strategi diferensiasi yang dilakukannya. Diselenggarakan di Yogyakarta, Djaduk Ferianto, konseptor dan penggagas bersama pemerhati musik di Yogyakarta mengusung musik jazz namun dibalut dengan semangat budaya lokal dan merakyat. Ngayogjazz memiliki cita-cita untuk ambil bagian dalam usaha pembangunan ekonomi dan sumber daya manusia masyarakat Yogyakarta. Telah menjadi agenda rutin sejak 2007, berikut data pengunjung Ngayogjazz: 


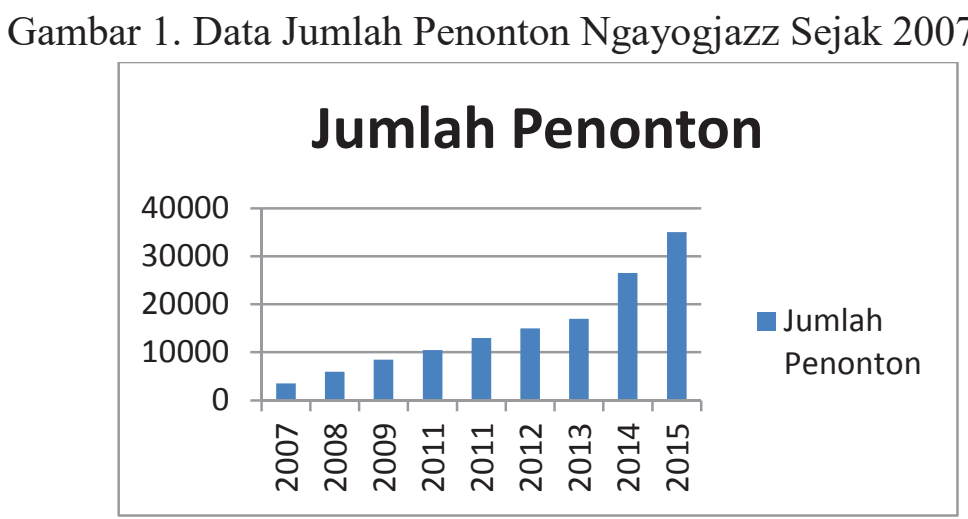

Sumber: Arsip Panitia Penyelenggara Ngayogjazz

Apresiasi masyarakat yang meningkat tiap tahunnya membuktikan penyelenggara memiliki strategi pemasaran yang berhasil. Konsep Ngayogjazz berbeda dengan ajang-ajang pertunjukan musik jazz yang tersebut sebelumnya. Penyelenggara memiliki misi yang lebih besar untuk disampaikan dengan media musik jazz. Penyelenggara ingin memberikan kontribusi bagi musik (karya seni), masyarakat, dan seniman (musisi). Ada proses berkelanjutan antara ketiganya yang ingin dibangun oleh para penyelenggara Ngayogjazz. Konsep yang unik dan berbeda ini seolah-olah menyiratkan Ngayogjazz menyusun sebuah strategi pengelolaan festival sebagai sebuah 'produk seni'.

Penelitian ini akan membahas penerapan strategi pemasaran terhadap pengelolaan seni pertunjukan dalam festival musik. Hasil dari penelitian ini adalah sebuah strategi pengelolaan seni pertunjukan musik yang ideal, dapat menjadi referensi dan pertimbangan bagi terselenggaranya festival-festival seni pertunjukan yang lain. Berdasarkan latar belakang ini, pertanyaan penelitian yang dirumuskan adalah sebagai berikut:

1. Bagaimana upaya Ngayogjazz membangun brand selama ini?

2. Mengapa strategi positioning dan diferensiasi penting untuk membangun brand Ngayogjazz?

3. Apakah strategi positioning dan diferensiasi tepat untuk membangun brand Ngayogjazz?

\section{Tinjauan Pustaka dan Kajian Teori}

Berdasarkan Joakim Bodin dan Jonatan Odby (2008), variabel yang digunakan dalam pembentukan brand adalah strategi pemasaran positioning dan diferensiasi. Sedangkan Ardiyanti (2014), meninjau teori strategi segitiga positioning, diferensiasi, dan brand (PDB). Proses pembentukan positioning menciptakan brand identity, mulai dari core identity, extended identity, value proposition, hingga brand essence. Positioning direalisasikan melalui diferensiasi dan kedua aspek tersebut harus terintegrasi. Saat ini penggunaan ilmu marketing masih sangat jarang diterapkan untuk pengelolaan festival di Yogyakarta. Penelitian ini akan menerapkan konsep Segitiga PDB untuk merumuskan strategi pemasaran yang digunakan oleh penyelenggara Ngayogjazz.

Proses penentuan positioning dapat dilakukan dengan menempuh proses analisis segmentasi dan target market. Segmentation, targeting dan positioning adalah salah satu strategi pemasaran bagian dari 9 elemen pemasaran dari Kotler. Analisis pasar merupakan 
upaya mengelompokkan konsumen potensial dalam kelompok-kelompok pasar khusus yang memiliki kesamaan respon terhadap variabel pemasaran. Langkah-langkahnya adalah dengan mendefinisikan segmen pasar, menyeleksi basis segmen, bentuk segmen, dan analisis segmen pasar (Hasan, 2013). Setelah itu perusahaan dapat menentukan segmen mana yang akan menjadi sasaran dari produk yang dihasilkan. Proses selanjutnya adalah analisis target pasar. Dalam proses ini perusahaan dibantu untuk mempertimbangkan segmen yang baik untuk dipilih, dikembangkan, dan harus ditinggalkan. Targeting diartikan sebagai proses evaluasi daya tarik segmen dan fokus tawaran yang paling cocok untuk sekelompok orang, wilayah, atau negara yang memiliki respon paling signifikan terhadap produk (Hasan, 2013).

Setelah proses penentuan segmen dan target pasar ini dilakukan, maka perusahaan dapat merumuskan posisi paling strategis yang dapat dibentuk bagi produk yang diproduksi. Positioning sendiri merupakan cara yang dilakukan untuk menciptakan faktor pembeda yang unik dalam benak pelanggan (target pasar) sehingga terbentuk citra merek atau produk yang lebih unggul dibanding produk pesaing (Hasan, 2013).

Segitiga PDB (Positioning, Diferensiasi, dan Brand) adalah salah satu teori dalam ilmu manajemen pemasaran, hasil turunan dari teori 9 Elemen Pemasaran yang terdiri dari brand, differentiation, positioning, segmentation, targeting, marketing mix, selling, service, dan process (Kartajaya,2004). Kartajaya mengelompokkan 9 elemen pemasaran ini dalam 3 bagian, strategi, taktik, dan value. Ketiganya merupakan satu kesatuan dengan peran khususnya masing-masing.

Gambar 2 : Bagan Segitiga PDB (Positioning, Diferensiasi dan Brand)

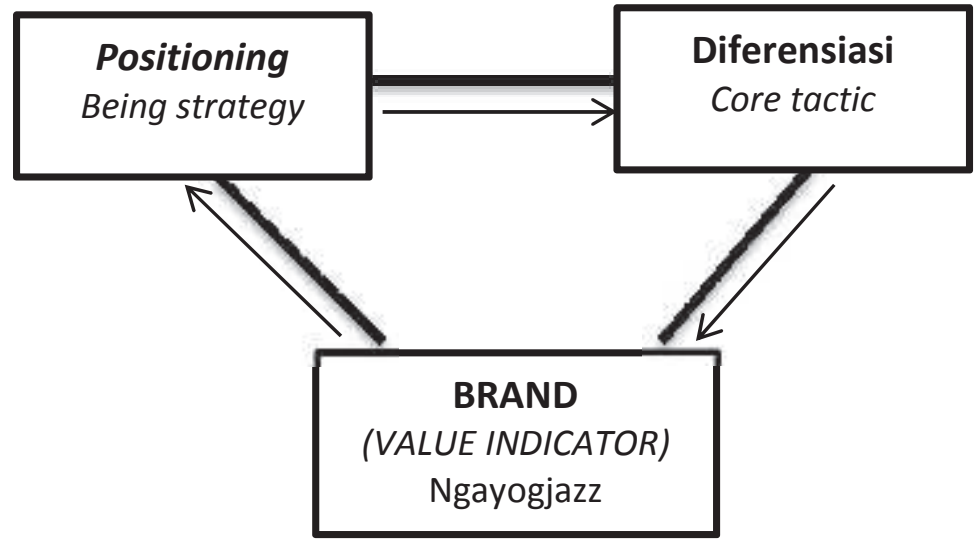

Sumber : Hermawan Kartajaya (2005, h.6)

Perusahaan harus dapat mengidentifikasi keunggulan produk agar dapat memutuskan positioning yang tepat untuk produk. Langkah selanjutnya adalah memilih beberapa keunggulan produk sebagai dasar membangun strategi positioning. Kriteria keunggulan positioning produk yang menurut Jobber (2004) adalah:

1. Clarity - posisi produk harus jelas dalam menggambarkan target pasar dan kekuatan diferensiasi.

2. Consistency - pesan yang konsisten dari positioning produk penting untuk memberi kekuatan bersaing bagi produk. 
3. Credibility - kekuatan diferensiasi harus kredibel dalam benak target pasar.

4. Competitiveness - kekuatan diferensiasi harus menggambarkan nilai produk untuk konsumen yang tidak dapat ditawarkan oleh produk pesaing.

Kartajaya (2005) berpendapat, diferensiasi adalah upaya mengintergrasi konten, konteks, dan infrastruktur pada penawaran produk kepada konsumen. Penawaran (offering) yang dilakukan perusahaan kepada konsumen tidak hanya harus dipersepsi berbeda, namun benar-benar berbeda dalam hal konten (what to offer), konteks (how to offer), dan faktorfaktor pemungkin (enabler). Proses saling menguatkan antar 3 elemen ini akan menciptakan self-reinforcing mechanism (proses penguatan secara terus-menerus). Self-reinforcing mechanism yang mampu berjalan dengan baik disebut virtuous circle.

Hasil dari proses ini adalah sebuah brand identity. Aaker \& Joachimsthaler (2000, h.44) menyatakan brand identity adalah seperangkat asosiasi yang diciptakan dan dipertahankan oleh perusahaan. Struktur brand identity terdiri dari core identity, extended identity, dan brand essence. Core identity harus merefleksikan strategi dan nilai dari organisasi pembuatnya. Extended identity mencakup elemen-elemen brand identity yang tidak ada dalam core identity. Brand essence merupakan pemikiran tunggal yang menangkap jiwa dari sebuah merek. Brand essence mempunyai karakteristik dapat menjangkau konsumen dan mengarahkan value proposition, memberikan diferensiasi dari pesaing, mampu bertahan dalam jangka waktu lama, serta mampu menginspirasi anggota organisasi. Value proposition merupakan proses penciptaan makna yang merepresentasikan nilai yang dimiliki dan akan disampaikan oleh sebuah merek. Makna tersebut dapat digambarkan secara rasional yang menekankan pada keuntungan fungsional (functional benefit) atau yang dapat merangsang perasaan (emotional benefits) sehingga konsumen merasa terhubung dengan merek (emotional \& self-expressive benefits).

\section{Metode Penelitian}

Penelitian ini merupakan penelitian lapangan yang dilakukan melalui metode kualitatif deskriptif dengan menggunakan pendekatan studi kasus. Instrument penelitian dalam metode kualitatif adalah peneliti sendiri dengan media pertanyaan penelitian yang telah disusun. Variabel yang digunakan adalah sebagai berikut:

Tabel 1. Variabel Penelitian

\begin{tabular}{|l|l|}
\hline Variabel & Sub Variabel \\
\hline Strategi Pemasaran & a. Positioning \\
& b. Diferensiasi \\
\hline Brand & a. core identity \\
& b. extended identity \\
& c. value proposition \\
& d. brand essence \\
\hline Pengembangan Strategi & a. konsep segitiga PDB \\
\hline
\end{tabular}

Sumber: Kajian landasan teori, 2016 
Subjek penelitian ini adalah strategi positioning dan diferensiasi untuk membangun brand pada festival musik Ngayogjazz. Objek penelitian yang dipilih adalah Festival Musik Ngayogjazz. Guna memperoleh keterangan yang mendalam tentang Ngayogjazz, peneliti memilih beberapa orang untuk menjadi narasumber dalam penelitian ini.

1. Djaduk Ferianto selaku konseptor dan board Ngayogjazz.

2. Aji Wartono dan Novindra Diratara selaku board Ngayogjazz dalam kesekretariatan, marketing, hubungan masyarakat dan hospitality.

3. Michael Raditya, Eri Setiawan, dan Prof. Dr. Heru Nugroho, sebagai jurnalis, pengamat seni, dan akademisi budaya di Yogyakarta.

Jenis data yang dibutuhkan dalam penelitian ini adalah data primer dan data sekunder. Data primer diperoleh secara langsung di lapangan melalui wawancara/ pertanyaan terbuka. Sedangkan data sekunder dikumpulkan melalui proses pengamatan langsung dan studi pustaka.

\section{Hasil dan Pembahasan}

\section{a. Strategi Positioning dan Diferensiasi Ngayogjazz}

Panitia penyelenggara Ngayogjazz mengaku tidak memiliki latar belakang ilmu marketing yang kuat untuk diterapkan dalam pengelolaan Ngayogjazz. Semua keputusan dalam tindakan pemasaran dilakukan berdasarkan konsep dari Djaduk Ferianto dan ide-ide kreatif panitia. Namun hasil wawancara menunjukkan bahwa tindakan-tindakan pengelolaan Ngayogjazz menunjukkan kesadaran pentingnya strategi positioning dan diferensiasi. Berikut rangkuman wawancara narasumber:

Tabel 2. Ringkasan Data Wawancara Strategi Positioning Ngayogjazz

\begin{tabular}{|c|c|c|c|c|}
\hline \multirow[t]{2}{*}{ No } & \multirow{2}{*}{$\begin{array}{l}\text { Atribut } \\
\text { positioning }\end{array}$} & \multicolumn{3}{|c|}{ Narasumber } \\
\hline & & $\mathbf{A}$ & B & $\mathrm{C}$ \\
\hline 1 & Clarity & $\begin{array}{ll}\text { - } & \text { ikon kota } \\
\text { Yogyakarta. } & \\
\text { - musik jazz rasa } \\
\text { Yogyakarta. }\end{array}$ & $\begin{array}{l}\text { - terbuka untuk semua } \\
\text { lapisan masyarakat. } \\
\text { - menempati ruang } \\
\text { yang lain. } \\
\text { - mengangkat konten } \\
\text { lokal. }\end{array}$ & $\begin{array}{l}\text { - } \text { menghadirkan } \\
\text { pengalaman- } \\
\text { pengalaman lain. } \\
\text { - unsur membangun } \\
\text { masyarakat dan } \\
\text { musisi lokal. }\end{array}$ \\
\hline 2 & Consistency & $\begin{array}{l}\text { - } \text { diselenggarakan } \\
\text { rutin. } \\
\text { - } \text { suasana lokal } \\
\text { Jogja. } \\
\text { - Penampilan } \\
\text { musisi lokal. }\end{array}$ & $\begin{array}{l}\text { - diselenggarakan } \\
\text { rutin. } \\
\text { - menampilkan musisi } \\
\text { lokal. } \\
\text { - memberdayakan } \\
\text { masyarakat. }\end{array}$ & $\begin{array}{lr}\text { - publikasi } & \text { melalui } \\
\text { semua } & \text { kanal } \\
\text { komunikasi. } & \end{array}$ \\
\hline 3 & Credibility & $\begin{array}{l}\text { - mencapai target } \\
\text { dari sponsor. } \\
\text { - Komunikasi yang } \\
\text { jelas }\end{array}$ & $\begin{array}{l}\text { - menyediakan fasilitas } \\
\text { terbaik } \\
\text { - profesionalitas } \\
\text { - komunikasi yang } \\
\text { jelas }\end{array}$ & 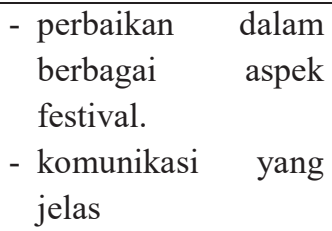 \\
\hline
\end{tabular}




\begin{tabular}{|c|c|c|c|c|}
\hline 4 & $\begin{array}{l}\text { Competitivenes } \\
S\end{array}$ & $\begin{array}{lr}\text { - festival dan } \\
\text { konser musik jazz } \\
\text { lain di } \\
\text { Yogyakarta. }\end{array}$ & $\begin{array}{l}\text { - menempati ruang } \\
\text { yang lain } \\
\text { - karakteristiknya } \\
\text { berbeda. }\end{array}$ & $\begin{array}{l}\text { - festival lain adalah } \\
\text { referensi } \\
\text { - mengisi ruang lain } \\
\text { bentuk pertunjukan } \\
\text { musik jazz. }\end{array}$ \\
\hline
\end{tabular}

Sumber: Olah data wawancara narasumber board Ngayogjazz, 2016

Strategi positioning Ngayogjazz didukung dengan langkah-langkah diferensiasi yang dirumuskan oleh board. Berikut merupakan rangkuman hasil wawancara tentang diferensiasi:

Tabel 3. Ringkasan Data Wawancara Diferensiasi Ngayogjazz

\begin{tabular}{|c|c|c|c|c|}
\hline \multirow[t]{2}{*}{ No } & \multirow{2}{*}{$\begin{array}{l}\text { Atribut } \\
\text { diferensiasi }\end{array}$} & \multicolumn{3}{|c|}{ Narasumber } \\
\hline & & $\mathbf{A}$ & B & $\mathrm{C}$ \\
\hline 1 & What to offer & $\begin{array}{l}\text { - spirit musik jazz } \\
\text { - macam-macam } \\
\text { genre } \\
\text { - musisi lokal }\end{array}$ & $\begin{array}{l}\text { - musik jazz } \\
\text { - musisi lokal } \\
\text { - konten-konten } \\
\text { lokal }\end{array}$ & $\begin{array}{l}\text { - gerakan kultural } \\
\text { - musisi lokal } \\
\text { - macam-macam } \\
\text { genre jazz } \\
\text { - kolaborasi seni }\end{array}$ \\
\hline 2 & How to offer & $\begin{array}{l}\text { - memberdayakan } \\
\text { masyarakat } \\
\text { - potensi ekonomi } \\
\text { desa } \\
\text { - mendukung } \\
\text { komunitas jazz } \\
\text { - gratis }\end{array}$ & $\begin{array}{l}\text { - } \text { suasana pedesaan } \\
\text { - jargon unik } \\
\text { menanggapi isu } \\
\text { sosial } \\
\text { - pemberdayaan } \\
\text { masyarakat } \\
\text { - gratis }\end{array}$ & $\begin{array}{l}\text { - diselenggarakan } \\
\text { di pedesaan } \\
\text { - pemberdayaan } \\
\text { masyarakat desa } \\
\text { - dekorasi dan } \\
\text { lokasi panggung } \\
\text { - Gratis } \\
\text { - Jargon plesetan } \\
\text { pepatah jawa }\end{array}$ \\
\hline 3 & Enabler & $\begin{array}{l}\text { - Masyarakat dan } \\
\text { budaya unik } \\
\text { - desa punya } \\
\text { potensi } \\
\text { - Board dengan } \\
\text { kapabilitas } \\
\text { masing-masing }\end{array}$ & $\begin{array}{l}\text { - potensi ekonomi } \\
\text { desa } \\
\text { - } \text { Board dengan } \\
\text { macam-macam } \\
\text { latar belakang, } \\
\text { saling melengkapi }\end{array}$ & $\begin{array}{l}\text { - } \text { Board dari } \\
\text { macam-macam } \\
\text { latar belakang, } \\
\text { kapabilitas board } \\
\text { sesuai bidangnya }\end{array}$ \\
\hline
\end{tabular}

Sumber: Olah data wawancara narasumber board Ngayogjazz, 2016

Ngayogjazz memiliki konsep yang matang untuk membentuk strategi positioningnya. Latar belakang penyelenggaraan Ngayogjazz untuk menjadi salah satu ikon Yogyakarta juga diikuti kesadaran board untuk ikut aktif dalam pembangunan aspek-aspek sosial masyarakat, tidak hanya dari aspek kesenian. Board menyadari banyak hal dapat dilakukan dan disampaikan melalui musik. Selain itu, konsep yang unik dan berbeda yang diusung oleh 
Ngayogjazz juga merupakan sebuah reaksi dari konsep pertunjukan dan festival musik jazz di Indonesia.

Festival jazz yang terselenggara di Indonesia seolah-olah membuat batasan segmen bagi masyarakat yang ingin mengapresiasi musik jazz. Melihat fenomena ini Ngayogjazz menyajikan musik jazz dengan konsep yang lebih terbuka untuk semua lapisan masyarakat, dapat menempati ruang yang lain, mengangkat konten-konten lokal, dan memberi prioritas bagi musisi-musisi lokal dari komunitas-komunitas jazz Indonesia. Ngayogjazz memposisikan diri sebagai festival musik jazz yang dapat diakses oleh semua segmen masyarakat. Konten-konten budaya lokal, tempat penyelenggaraan dan line up musisi dari komunitas-komunitas menjadi diferensiasi yang kokoh untuk brand yang ingin dibentuk.

Karena Ngayogjazz ingin mengakomodasi semua segmen masyarakat sebagai target pasarnya, maka semua kanal komunikasi dipakai untuk publikasi. Sosial media menjadi sarana publikasi yang paling murah dan efektif untuk dimasuki. Publikasi-publikasi dengan banyak kanal ini menjadi kekuatan Ngayogjazz untuk menyampaikan 'produknya' kepada masyarakat. Ngayogjazz juga mengundang banyak ahli dari bermacam-macam bidang untuk ikut terlibat di dalam konferensi pers, seperti sosiolog, antropolog, arsitek, desainer grafis, perupa, dan banyak lagi. "Biar masyarakat yang menyampaikan kepada masyarakat sendiri tentang Ngayogjazz," ujar Aji Wartono.

Konseptor dan board menggunakan media musik jazz untuk membuat sebuah peristiwa budaya. Board ingin menunjukkan bahwa banyak hal dapat dilakukan melalui musik. Ngayogjazz adalah sebuah gerakan kultural yang mampu menjadi penggerak untuk membangun masyarakat pendukung produk seni dan wadah berkumpulnya musisi dan masyarakat. Wujud nyata pembangunan masyarakat direalisasikan dengan pemberdayaan dan mengangkat potensi ekonomi desa.

Merealisasikan posisinya sebagai sebuah festival jazz yang terbuka, Ngayogjazz merumuskan strategi diferensiasi. Ngayogjazz memilih desa-desa di daerah Yogyakarta sebagai tempat penyelenggaraan acara. Desa-desa ini dipilih berdasarkan kriteria yang telah dirumuskan oleh board. Beberapa kriteria antara lain potensi atau nilai ekonomi desa yang dapat diceritakan kepada masyarakat yang lain, luas area, ketersediaan fasilitas, dan keterbukaan dari masyarakat desa untuk perijinan Ngayogjazz (wawancara dengan Aji Wartono). Hal ini menunjukkan bahwa tim Ngayogjazz melakukan kurasi terhadap tempat penyelenggaraan acara. Sistem kurasi tempat ini dapat dirumuskan sebagai salah satu strategi tim Ngayogjazz.

Strategi diferensiasi yang lain adalah balutan konten-konten lokal dalam Ngayogjazz. Konten-konten lokal yang paling tampak dapat dilihat pada dekorasi. Bahan-bahan pokok dekorasi dari desa dibentuk menjadi benda-benda dekorasi yang kemudian digunakan untuk dekorasi panggung, jalan setapak, dan titik-titik penting dalam acara. Beberapa panggung Ngayogjazz adalah sebuah pendopo atau teras rumah penduduk. Panggung ini selalu berhasil menghadirkan sebuah impresi yang lain bagi penonton. Jarak panggung yang dekat dan rendah membuat penonton dapat menikmati pertunjukan dengan lebih dekat. Kondisi panggung ini menimbulkan suasana yang dekat dan hangat. Bagi penonton yang berasal dari luar kota, suasana seperti ini yang menjadi khas dari Yogyakarta.

Konten-konten budaya lokal yang dapat diperkenalkan kepada masyarakat juga dihadirkan melalui ritual budaya. Dalam beberapa penyelenggaraan, Ngayogjazz 
menampilkan kesenian-kesenian lokal dalam ritus pembukaan acara maupun saat pertunjukan musik. Kesenian-kesenian lokal ini berkolaborasi dengan serangkaian pertunjukan lain saat ritus pembukaan Ngayogjazz. Beberapa bentuk kesenian lain yang hadir dalam Ngayogjazz seperti lukis tubuh dan pantomime juga selalu disajikan untuk penonton setiap tahunnya. Para seniman-seniman lukis tubuh dan pantomime akan menyebar di jalan-jalan setapak seputar tempat penyelenggaraan untuk menyapa penonton dan memamerkan karyanya.

Selain bahasa Indonesia, bahasa Jawa juga merupakan bahasa pokok yang digunakan untuk komunikasi dalam Ngayogjazz. Pembawa acara dalam Ngayogjazz adalah orang-orang yang fasih berbahasa Jawa dan Indonesia. Gaya bahasa santai, kocak, dan banyolan-banyolan berbahasa jawa menjadi salah satu kekhasan Ngayogjazz. Para pembawa acara ini menjadi salah satu faktor penting untuk menbangun suasana yang hangat dan meriah khas Ngayogjazz. Bahasa Jawa juga digunakan dalam jargon-jargon Ngayogjazz setiap tahunnya. Jargon ini dibuat oleh board sebagai respon terhadap isu-isu sosial yang terjadi di Yogyakarta maupun Indonesia.

Sampai tahun ini, jumlah penonton yang hadir selalu mengalami peningkatan yang signifikan. Narasumber wakil masyarakat mengaku dapat memperoleh setiap informasi tentang Ngayogjazz dengan mudah. Penonton yang hadir dapat berasal dari manapun, berlatar belakang berbeda, memiliki selera musik berbeda, dan memiliki tujuan yang berbeda-beda. Beberapa narasumber yang ditemui sepakat mengatakan bahwa festival ini adalah salah satu gerakan sosial yang penting untuk diselenggarakan.

Ngayogjazz berhasil menempati ruang yang lain sebagai salah satu bentuk festival musik jazz. Keberadaannya hampir tidak memiliki pesaing karena saat munculnya dulu Ngayogjazz adalah satu-satunya festival musik jazz dengan gaya kebudayaan jawa yang kental. Bagi masyarakat, Ngayogjazz dapat menjadi alternatif utama jika ingin menyaksikan pertunjukan musik jazz dengan cara yang lebih kasual.

\section{b. Brand}

Konsep brand ini merupakan analisis peneliti terhadap hasil wawancara dengan Djaduk Ferianto yang telah dikonfirmasi oleh Aji Wartono dan Vindra Diratara. Hasil wawancara dengan board ini kemudian dibandingkan dengan pandangan masyarakat tentang Ngayogjazz. Berikut merupakan hasilnya:

\section{Tabel 7. Brand identity Ngayogjazz}

\section{Core identity}

a. Festival

Dasar dari Ngayogjazz adalah gagasan untuk membuat sebuah festival sebagai ikon Yogyakarta. Ngayogjazz diselenggarakan sebagai suatu peristiwa kesenian dan sarana bertemunya masyarakat.

b. Musik jazz

Pemilihan media musik jazz karena sedang berkembang di Yogyakarta dan Indonesia, genre musik yang fleksibel, dan semangat memperkenalkan musik jazz bagi masyarakat tanpa segmentasi apapun.

c. Konten-konten budaya lokal 


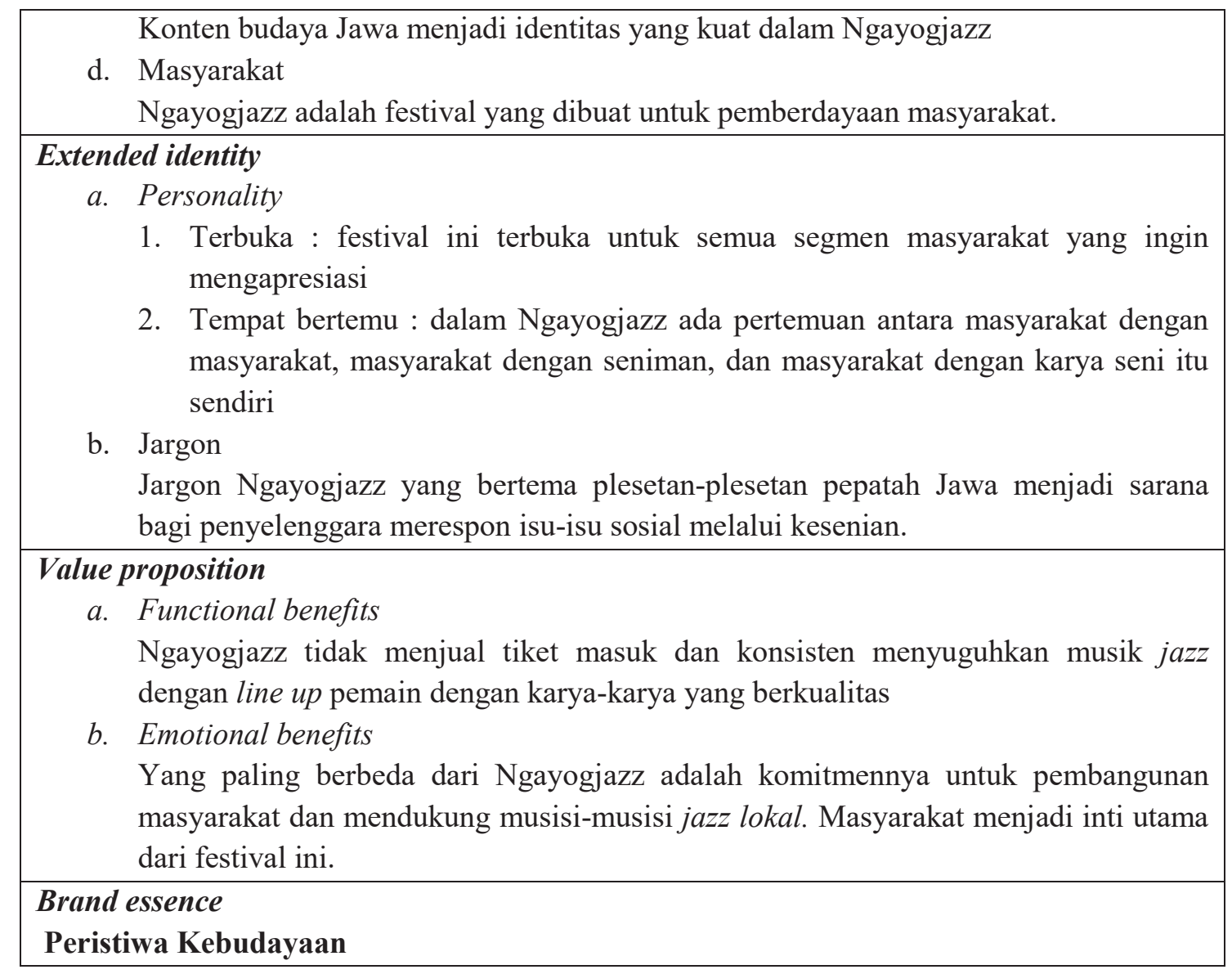

\section{Pembahasan}

\section{Usaha Ngayogjazz Membentuk Brand}

Penyelenggara Ngayogjazz memiliki keinginan yang jelas untuk membentuk brand. Nama Ngayogjazz sendiri yang merupakan gabungan kata Ngayogyakarta (Yogyakarta) dan jazz (musik jazz) merupakan salah satu strategi pembentukan brand untuk festival ini. Telah dibangun dari tahun 2007 hingga kini, brand Ngayogjazz semakin kuat terbentuk. Kekuatan ini tidak lepas dari strategi positioning dan diferensiasi yang telah dilakukan.

Positioning Ngayogjazz adalah festival jazz yang terbuka bagi semua segmen masyarakat. Tidak melakukan segmentasi dan tidak menentukan target market menjadi strategi yang ditempuh agar Ngayogjazz dapat diapresiasi oleh siapa saja yang bersedia datang merasakan pengalaman pertunjukan musik yang berbeda dalam festival ini. Karena terbuka untuk diapresiasi oleh siapapun, Ngayogjazz menjadi sebuah festival musik jazz yang lebih merakyat. Penyelenggaraan Ngayogjazz menjadi sebuah peristiwa kebudayaan tempat bertemunya masyarakat dengan masyarakat, masyarakat dengan musisi, dan masyarakat dengan kesenian itu sendiri.

Faktor pembeda Ngayogjazz yang paling tangible adalah tempat penyelenggaraan acara dan balutan konten-konten budaya lokal. Hal ini menjadi kekuatan terbesar Ngayogjazz untuk menawarkan sesuatu yang baru dalam penyelenggaraan seni pertunjukan. Desa berhasil menghadirkan suasana yang berbeda untuk menikmati musik jazz. Panggung-panggung Ngayogjazz dikemas sedemikian rupa agar tercipta suasana dekat dengan penonton. Beberapa panggung dibuat rendah sehingga penonton dapat duduk santai beralas tanah untuk 
menikmati sajian musiknya. Dengan semua konsep ini selalu tercipta suasana khas dari Ngayogjazz. Hal ini yang dirindukan oleh penonton.

Proses sejak 2007 hingga kini, Ngayogjazz semakin menunjukkan profesionalitas pengelolaannya (dalam hal ini adalah pembentukan brand). Dengan perumusan brand identity yang akhirnya dikomunikasikan melalui strategi positioning dan diferensiasi, Ngayogjazz akan membangun brand equity. Brand equity adalah intangible asset yang dimiliki oleh sebuah merek karena value yang diberikannya baik kepada produsen maupun konsumen (Kartajaya, 2004: 197).

Tesis ini tidak membahas lebih lanjut tentang ekuitas merek yang dimiliki Ngayogjazz sejauh ini. Namun Ngayogjazz terbukti menjadi brand yang kuat di Yogyakarta saat ini. Hal ini ditunjukkan secara nyata melihat banyaknya sponsor dan media partner yang bersedia bekerja sama dengan Ngayogjazz dalam setiap penyelenggaraannya. Sponsor-sponsor ini menunjukkan loyalitasnya untuk mendukung Ngayogjazz dari tahun ke tahun. Hal ini membuktikan tejadi selfreinforcing mechanism (penguatan terus menerus) dalam brand Ngayogjazz. Artinya, strategi positioning dan diferensiasi yang dilakukan Ngayogjazz berhasil.

\section{Ngayogjazz Dalam Pandangan Masyarakat}

Semua narasumber yang mewakili masyarakat berpendapat Ngayogjazz telah berhasil menjadi sebuah brand. Strategi positioning dan diferensiasi yang dilakukan pihak penyelenggara sebagian besar dapat tersampaikan kepada masyarakat. Dengan kekuatan brand ini, Ngayogjazz mampu menarik minat dan loyalitas masyarakat untuk hadir dan mengapresiasi. Masyarakat yang berhasil dirangkul oleh Ngayogjazz merasa ikut memiliki festival ini untuk memenuhi kebutuhan estetis dalam dirinya. Peristiwa yang dibuat Ngayogjazz dapat memenuhi kebutuhan masyarakat sebagai makhluk sosial.

Banyak hal dapat dikembangkan Ngayogjazz untuk memperkuat brand. Salah satunya dengan memperhatikan kritik masyarakat dalam perbaikan hal-hal teknis pertunjukan dan line up pengisi acara. Ngayogjazz memiliki tanggung jawab untuk meningkatkan kualitas pertunjukan dan penggarapan dinamika panggung. Hal ini harus dilakukan untuk memuaskan penonton dengan segmen pengetahuan musikal yang lebih tinggi. Jika segmen-segmen baru berhasil dirangkul untuk belajar mengapresiasi musik jazz, segmen-segmen masyarakat yang telah lama menjadi penikmat musik jazz juga turut merasakan peningkatan kualias Ngayogjazz benar-benar sebagai festival musik jazz.

Terlepas dari berbagai tanggapan positif dan saran-saran memberbaiki kekurangan, masyarakat sependapat bahwa festival dengan bentuk seperti Ngayogjazz harus tetap diselenggarakan. Ngayogjazz dapat menjadi sebuah sarana bagi seniman seni pertunjukan dan penyelenggara untuk belajar menyelenggarakan festival yang ideal. Ngayogjazz akan menjadi sebuah ajang lahirnya musisi-musisi muda dan pengelola-pengelola kesenian yang berpotensi menjadi yang terbaik nantinya. Kesimpulannya, di balik sebuah festival musik, Ngayogjazz memiliki mimpi yang lebih besar untuk menjadi wadah yang menggerakkan nilai-nilai budaya Yogyakarta melalui media musik jazz. 


\section{Penerapan Teori Segitiga PDB dalam Ngayogjazz}

Ngayogjazz adalah sebuah 'produk' seni, dapat diandaikan sebagai sebuah produk (benda) yang ingin dijual (dipasarkan) kepada konsumen. Dalam kasus ini konsumen adalah masyarakat, penonton festival Ngayogjazz. Sedangkan produser (perusahaan) adalah pihak penyelenggara festival (board dan panitia. Perbedaan signifikan terletak pada nilai yang tangible dan intangible dari produk.

Sebuah perusahaan yang akan memasarkan produknya kepada konsumen memiliki tujuan yang jelas untuk mendapatkan keuntungan yang tangible dan intangible. Jika perusahaan dapat menentukan strategi pemasaran yang pas untuk produk, maka produk akan mendapat tempat di benak masyarakat. Permintaan produk akan meningkat sehingga menghasilkan keuntungan tangible bagi perusahaan berupa materi. Selain itu, memenangkan posisi di benak masyarakat juga dapat membuat perusahaan memperoleh nilai intangible berupa kepercayaan masyarakat akan perusahaan tersebut. Proses ini yang sedikit demi sedikit akan membentuk kekuatan brand bagi perusahaan.Ngayogjazz adalah sebuah produk kesenian yang diproduksi oleh board (seniman-seniman Yogyakarta). Board menyatakan bahwa festival ini memang diselenggarakan bukan untuk memperoleh keuntungan finansial. Peneliti menyimpulkan terkandung nilai-nilai intangible yang lebih kuat dalam Ngayogjazz yang ingin diraih oleh board.

Tidak berorientasi pada profit, strategi pemasaran Ngayogjazz membutuhkan banyak penyesuaian untuk dilakukan. Selain itu melihat sifat sebuah seni yang dinamis juga tidak dapat disamakan dengan sebuah produk benda mati yang ditawarkan produsen kepada konsumen. Jika strategi pemasaran yang konfensional melihat masyarakat (konsumen) sebagai inti pokoknya, ada 3 aspek yang sangat menentukan pemasaran Ngayogjazz, yaitu masyarakat, seniman, dan karya seni itu sendiri. Pemasaran sebuah produk seni tidak hanya melihat permintaan atau kepentingan masyarakat sebagai inti, namun juga harus memperhatikan kepentingan seniman sebagai produsen dan karya seni itu sendiri sebagai produknya. Tiga aspek ini berhubungan satu sama lain dan tidak boleh diabaikan.

Sama dengan segitiga PDB, aspek seniman, masyarakat, dan karya seni juga saling terkait satu sama lain. Ketika ingin memasarkan sebuah karya seni, seniman berhak menanamkan idealisme dan kepentingannya di situ. Aspek masyarakat tidak lagi merupakan satu-satunya hal yang menjadi acuan pokok penentuan strategi pemasaran. Melalui karya seni yang dibuat, seniman dapat menyampaikan banyak hal atau membuat banyak hal untuk dan kepada masyarakat. Misalnya dalam Ngayogjazz, board memiliki kepentingan lain di luar kebutuhan masyarakat terhadap pertunjukan musik. Melalui Ngayogjazz, board memiliki visi dan misi untuk membangun apresiasi masyarakat terhadap karya seni, khususnya musik jazz. Jika masyarakat memiliki apresiasi yang tinggi terhadap musik, maka musisi juga tentu tidak akan kesulitan mendapatkan apresiasi untuk karyanya.

Strategi pemasaran juga harus melihat kepentingan karya seni itu sendiri. Kesenian adalah sesuatu yang sangat dinamis. Perubahannya sering tidak terprediksi dan masiv. Apresiasi masyarakat juga sangat dinamis tergantung dengan tren kesenian yang berubah. Dalam Ngayogjazz, board harus dapat merumuskan strategi apa yang pas untuk pemasaran musik jazz. Board ingin menciptakan apresiator-apresiator baru untuk musik jazz yang tadinya terkesan elit. Oleh karena itu dalam Ngayogajazz, musik jazz dihadirkan dengan konsep yang dekat dengan masyarakat, responsif, dan komunikatif. 
Board Ngayogjazz terbukti mampu merumuskan strategi pemasaran yang tepat untuk festival ini. Namun karena tidak mengacu secara sengaja terhadap teori PDB, maka beberapa hal perlu ditinjau ulang oleh penyelenggara. Penjabarannya adalah sebagai berikut:

Pihak board mendapatkan kedudukan baik dalam hal clarity dan consistency pada positioning Ngayogjazz. Strategi pemasaran yang terkait dua hal ini dapat ditangkap dengan mudah oleh masyarakat. Terbukti pernyataan masyarakat cocok dengan harapan penyelenggara. Namun, Ngayogjazz perlu memperhatikan aspek credibility dan competiiveness. Bagaimanapun Ngayogjazz telah mengangkat musik jazz sebagai konten utama dalam pertunjukannya. Konsekuensi dari tidak melakukan segmentasi dan target market adalah berusaha mengakomodasi semua penonton yang hadir di Ngayogjazz.

Beberapa penonton merasa sangat terpuaskan dengan line up pemain yang disajikan, namun beberapa penonton mengaku di beberapa kesempatan merasa tidak ada yang 'baru' dari pertunjukan di Ngayogjazz. Pengaturan dinamika panggung dan pemilihan line up pemain dapat menjadi salah satu strategi untuk mengatasi hal ini.

Tidak berorientasi pada profit, board mengaku tidak menganggap festival-festival musik maupun festival bentuk lain sebagai saingan melainkan sebagai referensi. Hal ini masih relevan untuk dilakukan hingga sekarang, karena minat masyarakat terhadap musik jazz masih tinggi. Namun melihat sifat seni yang sangat dinamis, tidak menutup kemungkinan selera masyarakat akan berubah terhadap sebuah kesenian. Oleh karena itu Ngayogjazz perlu memperhatikan bentuk-bentuk festival lain sebagai kompetitor. Hal ini positif karena akan memacu board dan panitia untuk selalu up to date, kreatif dan inovatif dalam konsep Ngayogjazz.

\section{Kesimpulan}

Penelitian ini menggunakan variabel-variabel yang mampu merumuskan strategi positioning dan diferensiasi yang dilakukan penyelenggara festival untuk Ngayogjazz. Berdasarkan datadata dalam analisis yang sudah dilakukan di atas, signifikansi dapat disimpulkan sebagai berikut:

1. Upaya membangun brand telah dilaksanakan pihak penyelenggara Ngayogjazz dengan menerapkan strategi-strategi pemasaran sesuai dengan ide-ide kreatif mereka. Panitia penyelenggara Ngayogjazz telah menerapkan strategi positioning dan diferensiasi walaupun tidak secara sadar dan tidak belajar dari teori secara langsung. Penerapan strategi ini membentuk sebuah brand bagi Ngayogjazz.

2. Strategi positioning dan diferensiasi tepat untuk diterapkan dalam pemasaran Ngayogjazz. Hal ini disebabkan karena Ngayogjazz adalah sebuah festival musik jazz dengan konsep yang baru, berbeda dengan konsep-konsep pertunjukan musik jazz yang telah ada. Strategi positioning dan diferensiasi yang tepat dapat membantu Ngayogjazz agar dikenal dan dapat diapresiasi oleh masyarakat.

3. Teori segitiga PDB menunjukkan pentingnya penerapan strategi positioning dan diferensiasi bagi Ngayogjazz. Hal ini dibuktikan dengan terbentuknya brand yang kuat pada Ngayogjazz. Beberapa manfaat terbentuknya brand dalam Ngayogjazz adalah tercapainya kredibilitas yang tinggi dan apresiasi yang selalu meningkat dalam setiap penyelenggaraan Ngayogjazz setiap tahunnya. 


\section{Kepustakaan}

Buku:

Allen, J, William O'Toole, dkk. 2010. Festival \& Special Event Management $5^{\text {th }}$ Edition. Milton: The Wiley Advantage.

Chong, D. 2010. Arts Management. New York: Routledge.

Creswell, J. W. 2010. Research Design Pendekatan Kualitati, Kuantitatif, dan Mixed. Yogyakarta: Pustaka Pelajar.

Hasan, A. 2013. Marketing dan Kasus-Kasus Pilihan.Yogyakarta: CAPS.

Hauptfleisch, T. 2007. Festivalizing. Brill, Rodopi.

Kartajaya, H \& Yuswohady. 2005. Positioning, Diferensiasi, \& Brand Concepts: Strategy That Works. Jakarta: PT. Gramedia Pustaka Utama

Kotler, P. 2005. Manajemen pemasaran (Edisi 11), Jakarta: PT. Indeks Kelompok Gramedia.

Miles, M.B. \& Huberman, A.M, 1994. Qualitative Data Analysis. Thousand Oaks: Sage Publications.

Ries, A \& Jack Trout. 2000. Positioning - The Battle for Your Mind. Warner Books.

Thompson, A \& A.J. Strickland. 1998. Strategic Management Concepts and Cases, 10th edition. Boston: McGraw-Hill.

Yin, R. K. 2005. Studi Kasus, Desain dan Metode. Jakarta: PT Raja Grafindo Persada.

Jurnal:

Aaker, J.L. 1997. Dimensions of Brand Personality.

Ardiyanti, F. 2014. Strategi Positioning dan Diferensiasi dalam Upaya Membangun Brand Legipait Coffeeshop.

Biel, A.L. 1992. How Brand Image Drives Brand Equity.

Bodin, J \& Odby, J. 2008. Positioning and Brand Personality within Research Charity Organization.

Murgiyanto, Sal. 2014. Membaca Festival, Menyimak IIMF 2014.

Rosilawati \& Reagan. 2009. Strategi Positioning Slank dalam Menanamkan Citra sebagai Salah Satu Grup Band di Indonesia. 